\title{
The role of non governmental organizations in monitoring and evaluating public policies, measuring the effects stressing the impact on regional economic policy implementation
}

\author{
Viorina - Maria Judeu, Agora University of Oradea, Romania
}

\begin{abstract}
Regional policy implementation encounters difficulties and limitations similar to those for other areas of economic policy. The main difficulties are those arising from uncertainty in the gaps of time and the nature of the political climate. As a variant influencing the selection process by which a public interest issue to be solved and the stages of monitoring / evaluation of the implementation of public policies are often part of the current work of NGOs. Depending on the area of expertise / interest for a particular topic at a time, NGOs have chosen to monitor / assess the performance of authorities in implementing a solution to solve a problem, depending on certain parameters.
\end{abstract}

\section{Keywords}

governmental organizations, European policies, economic development, regional disparities.

JEL Codes: L31, L38, R58

Regional policy implementation encounters difficulties and limitations similar to those for other areas of economic policy.

The main difficulties are those arising from uncertainty in the gaps of time and the nature of the political climate.

Time creates problems inherent gaps, concerning the implementation of economic policies relating to: ${ }^{1}$

- identify problems that address to the economic policy;

- describe and implement the best policy;

- initial effect of policy on the regional economy;

- side effects multiplier in the regional economy.

The effect of these differences in time on the implementation of regional policy can be illustrated, for example, by carrying out a scheme for retraining and job recycling factor, which includes several stages.

The first stage would be to identify the problem to the policy. In our example, it is the work factor, in a certain region, which is characterized by a small number of workers with a certain qualification.

After identifying the problem, the policy response will be to describe and implement a policy to achieve more local programs for training in occupations found to be in deficit.

The policy response needs some time until new qualified employment factor can be effectively employed.

Only after overcoming this phase, the initial effect of policy may be perceived as increasing the supply of skilled workers for a particular local labor market. Secondary multiplier effects will be felt also, but after another interval. ${ }^{2}$

\footnotetext{
${ }^{1}$ Ionescu R, Marchis G., Uniunea Europeană- prezent şi perspective Ed. Didactică şi Pedagogică, Bucureşti, 2004.
} 
But reality shows that the time needed to achieve growth in the working of a particular qualification, through regional policies may be large enough so that local and national circumstances to amend and cause a reduction in market demand for skilled local employment factor.

Uncertainty may also be highlighted on the previous example. Thus, one can not know how to develop application for classification that, in the coming years.

As a result, policy makers have only incomplete information related to future periods and reduced opportunities for intervention in this area.

Policy environment: regional policy, and other economic policies are implemented in the context of certain political objectives. Thus, measures, anti-unemployment, macroeconomic, will necessarily affect these phenomena and regional levels. Moreover, regional policy is a policy response to the wishes of the people voting in a particular territory. ${ }^{3}$

So if, for example, residents of Scotland and the North of England vote Labor Party in a proportion so large those conservative candidates have no real chance of being elected there will be a very small concern, from any conservative government to financially support these areas. Basically, most of the money spent will move to regions of the ruling party honest.

Measuring the effects of regional policy is basically to compare costs with the results of these policies. The indicator most often used for this purpose is the number of jobs created on the basis of costs incurred in this respect, at regional level.

The cost of implementing a specific government regional policy is known and can be easily quantified. Where regional policy expenditures are reflected in the classification factor substitution work and location of firms, number of jobs directly created is also easy to estimate.

But reality shows that the effects of regional policies are more complex than those related to the number of new jobs created. Moreover, the initial costs of regional policy can have positive multiplier effects more difficult to quantify.

Cost - benefit analysis from the regional policy was introduced by Armstrong and Taylor, as highlighted in the following table. ${ }^{4}$

Table 1: The main costs and social benefits of regional policies

\begin{tabular}{|l|l|l|l|}
\hline \multicolumn{2}{|c|}{ Benefits (B) } & \multicolumn{2}{c|}{ Costs (C) } \\
\hline B1 & $\begin{array}{l}\text { The employment factor, } \\
\text { production and additional } \\
\text { income achieved from increased } \\
\text { economic activities; } \\
\text { Decreased number of migrants, } \\
\text { which leads to reduced costs for } \\
\text { public sector services and } \\
\text { infrastructure implementation } \\
\text { Decreased number of migrants, } \\
\text { which leads to reduced private } \\
\text { costs of migration; } \\
\text { Decrease externalities }\end{array}$ & C3 & $\begin{array}{l}\text { Loss of production, income and } \\
\text { employment }\end{array}$ \\
B3 & C4 & $\begin{array}{l}\text { Infrastructure costs resulting from } \\
\text { the effects of regional policy on } \\
\text { development of economic } \\
\text { activities; } \\
\text { The costs of moving to a new } \\
\text { location of production capacities; } \\
\text { Fair benefits; }\end{array}$ & $\begin{array}{l}\text { Increase externalities (e.g.: For } \\
\text { environmental protection); } \\
\text { Administrative costs }\end{array}$ \\
B5 & C5
\end{tabular}

${ }^{2}$ Bachtler J., Wren C. ,Evaluation of European Union, cohesion policy: research questions and policies changes, Regional Studies, vol 40, no. 2, April 2006.

${ }^{3}$ Cochran Ch. L., Malone Eloise F., Public policy, Viva Books Private Limited, 2007.

${ }^{4}$ Armstrong H., Taylor J., Regional Economics and Policy, Blackwell, $2^{\text {nd }}$ edn., 2000, pp.14 - 15. 


\begin{tabular}{|l|l|l|l|}
\hline \multicolumn{2}{|c|}{ Benefits (B) } & \multicolumn{2}{c|}{ Costs (C) } \\
\hline B6 & Political benefits & C6 & Political costs \\
\hline
\end{tabular}

The first benefit B1 is the result of regional expenditure policy. These costs have two categories of effects: the direct, the level of economic activity in developed regions and secondary indirect, which takes the form of influence of regional multiplier. Regional economic multiplier value is crucial in determining the actual costs of expenditure policies. The multiplier value will be greater; the greater will be the overall positive effect of regional expenditure policy. If the regional expenditure policy is successful, it will have the effect of reducing interregional differences related to employment opportunities and income levels.

As a result, the benefits of $\mathbf{B} \mathbf{2}$ and $\mathbf{B} 3$ will be achieved due to the reduction of interregional migration. Where employment opportunities and incomes are higher, more and more immigrants arrive from less developed regions. Migration imposes costs for both immigrant (private costs of migrants) and society (social costs of migration). A decrease of interregional migration flows will result in a reduction of migration costs at private and social. Private costs are the financial (relating to moving house) and those related to leaving social environment (family and friends). Social costs of migration concerns the construction of more housing, schools, hospitals in a given region.

The following benefit B4 regional policy from a spatial distribution of the negative externalities, e.g. pollution. If it is considered that pollution has a cumulative effect on the environment, then we will pursue the reduction of the concentration of polluting firms in a given area.

B5 benefit refers to the fact that regional policy differences in income and reduced expansion of the income distribution. Concentration of revenue from the economic activities in a subsection of the space economy is not fair. Therefore, the presence of policies such as progressive income taxes will have a beneficial effect on mitigating inter-regional differences.

However, interregional differences in income levels may reveal other sources of spatial inequality such as differences in regional access to better paying jobs, education or health care.

Finally, an active regional policy allows obtaining and political benefits B6. Interregional differences lead to a political cohesion of the whole nation. Thus, in Italy, Northern Areas have become allies in politically in the early '90s, as a result of higher fees they are required to pay to support the development of southern regions. Therefore, national economic unit will contribute to a political unit. Thus, regional politics will get political benefits, as well as economic and social.

Often, regional policies resulting in the employment of resources that, until then, were not used. In such cases, additional economic activity that will occur will not be independent from political intervention. Creating these additional economic activities leading to achievement of economic and social benefits with very low costs.

If the resources are drawn from an economic activity to another, regional policy will invoke a certain opportunity cost $(\mathrm{C} 1)$. Political benefit will appear as the net benefit due to the increased economic activity following the direction of resources from less productive activities to the most productive.

When regional policy is aimed at transferring resources from productive activities to the least productive, the company will bear a net cost exceeds the benefits obtained.

The second category of costs identified in the table (C2), are associated infrastructure elements. Thus, in areas predominantly rural infrastructure elements such as, proper roads are not sufficient, while in industrial areas is the question of the road relocation to optimize access. The relocation involves additional items of expenditure. These costs include labor costs moving factor in the new locations of production capacity (C3) and not all cases are covered by funds received from the government. In addition, costs appear to attracting and 
labor necessary to replace workers who do not want to change jobs, and expenditure on construction of new buildings and modernization of related. All the relocation costs associated with regional policy.

When regional policy is aimed at transferring resources from productive activities to the least productive, the company will bear a net cost exceeds the benefits obtained.

Expenditure category fourth $(\mathrm{C} 4)$ draw attention to the potential impact of regional policy environment for the benefit of the region analyzed. These costs should be reduced where relocation causes extensive retooling of existing industrial capabilities.

Cost category (C5) are those related to administrative costs associated with implementing regional policies. The absence of these policies that attract no cost. Finally, there are political costs (C6) regional policies related assets, as in regions of northern Italy, previously analyzed. In general, regional political costs may be attractive to those who vote (voters) in areas covered by these policy measures.

All these elements show that regional policy is not implemented at low cost. It is therefore important to create additional economic activity only to diversify existing ones, and money spent to maximize the benefits available to the region concerned.

As a variant influencing the selection process by which a public interest issue to be solved and the stages of monitoring / evaluation of the implementation of public policies are often part of the current work of NGOs. Depending on the area of expertise / interest for a particular topic at a time, NGOs have chosen to monitor / assess the performance of authorities in implementing a solution to solve a problem, depending on certain parameters.

The instruments used in this stage vary, depending on the type of method of monitoring / evaluation used, namely: ${ }^{5}$

- quantitative-methods (e.g. survey among beneficiaries of public policy measures, measuring dynamic parameters of public policy at the start of the measure to a certain length, etc..), Will use appropriate instruments: questionnaire, performance indicators, monitoring the press;

- qualitative-methods, instruments are typical of each type of method: interviews (interview guide), participatory observation (observation form), focus-group site (report discussion group), visits / inspections (report of visit/ inspection etc.).

Monitoring / evaluation of public policies by the NGOs is a democratic mechanism type checks and balances that basically is very useful for closing the public policy cycle. Since the results of evaluations made by the organization both initiatives, as well as external actors such as NGOs, indicates that a public policy issue has been resolved successfully, then the authority may proceed to resolve the following issues on the agenda.

But there are situations in which the problem can be reached on the agenda again in another form, or exactly the same form as originally proposed, the extent of settlement option implemented has not generated the intended results.

\section{Assessment highlights:}

- extent that the results match those originally fixed implementation;

- relationship between costs and results;

- timeliness and content of activities;

- impact on target groups.

In the evaluation, the employee who performed assessment (typically, it must be different from the implementing agency) use performance indicators. These indicators are closely related with the policy objectives and help to measure their achievement.

- The indicators used in evaluating public policy are classified into several categories:

- Input indicators:- measure the resources allocated for implementation of public policies (e.g. staffing, resources, etc.)

${ }^{5}$ Zaccomer G.P., Shift-Share Analysis with Spatial Structure: an Application to Italian industrial Districts, Transition Studies Review, Springer Wien, Volume 12, no.1, 2006. 
- outcome- indicators: quantifying the results in absolute terms: the number of people vaccinated, etc. number of publications distributed; impact- indicators: productivity rate, the share number of university graduates in the labor market, etc.

Table 2: indicators ${ }^{6}$

\begin{tabular}{|c|c|c|c|c|}
\hline Sector & Used resources & Results & Effects & Process \\
\hline Administration & $\begin{array}{l}\text { Number } \\
\text { persons }\end{array}$ & $\begin{array}{l}\text { Number of } \\
\text { documents of } \\
\text { public politics }\end{array}$ & $\begin{array}{l}\text { Better } \\
\text { decisions }\end{array}$ & $\begin{array}{l}\text { Opening to } \\
\text { the debates }\end{array}$ \\
\hline Education & $\begin{array}{l}\text { The report } \\
\text { student/professor }\end{array}$ & $\begin{array}{l}\text { Transition } \\
\text { rates between } \\
\text { courses of } \\
\text { study }\end{array}$ & $\begin{array}{l}\text { High level of } \\
\text { literacy }\end{array}$ & $\begin{array}{l}\text { Encourage } \\
\text { students to } \\
\text { express }\end{array}$ \\
\hline Juridical system & Budget & Trialed cases & $\begin{array}{l}\text { Low number } \\
\text { or appeals }\end{array}$ & $\begin{array}{l}\text { To assist } \\
\text { poor } \\
\text { defendants }\end{array}$ \\
\hline Police & $\begin{array}{l}\text { Number of police } \\
\text { cars }\end{array}$ & $\begin{array}{l}\text { Number of } \\
\text { arrests }\end{array}$ & $\begin{array}{l}\text { Low rate of } \\
\text { criminality }\end{array}$ & $\begin{array}{l}\text { Respecting } \\
\text { the rights }\end{array}$ \\
\hline Prisons & $\begin{array}{l}\text { Costs for each } \\
\text { imprisoned }\end{array}$ & $\begin{array}{l}\text { Number } \\
\text { imprisoned }\end{array}$ & Recidive rate & $\begin{array}{l}\text { Preventing } \\
\text { abuses }\end{array}$ \\
\hline Health & $\begin{array}{l}\text { Number of } \\
\text { assistants } \\
\text { according to the } \\
\text { size of population }\end{array}$ & $\begin{array}{l}\text { Number } \\
\text { vaccines }\end{array}$ & $\begin{array}{l}\text { Low rate of } \\
\text { mortality }\end{array}$ & $\begin{array}{l}\text { Care for the } \\
\text { patient }\end{array}$ \\
\hline Social aid & Social assistants & $\begin{array}{l}\text { Persons under } \\
\text { care }\end{array}$ & $\begin{array}{l}\text { Going outs of } \\
\text { the system }\end{array}$ & $\begin{array}{l}\text { Treatment } \\
\text { people with } \\
\text { respect }\end{array}$ \\
\hline
\end{tabular}

Measurement / assessment have a number of limitations related mainly to the fact that:

- provides- information only about the results and impact, but does not offer clues about what the way forward (including the prospect of a new problem appeared to be related in connection with public policy proposed for implementation);

- do not provide- information about how to place the implementation (of the process itself);

- do not provide- information about the divergent positions of stakeholders;

- $\quad$ are usually- associated with a dualistic approach (vs. punishment. Premiere).

\section{Bibliography:}

1. Armstrong H., Taylor J., Regional Economics and Policy, Blackwell, $2^{\text {nd }}$ edn., 2000,

2. Bachtler J., Wren C. ,Evaluation of European Union, cohesion policy: research questions and policies changes, Regional Studies, vol 40, no. 2, April 2006.

3. Cochran Ch. L., Malone Eloise F., Public policy, Viva Books Private Limited, 2007.

4. Gerston N. Larry, Public policymaking: process and principles, (second edition), Center for Civic Education, 2004.

6 Schiavo-Campo Salvadore, Strenghtening Performance in Public Expenditure Management, 1995. 
5. Ionescu R, Marchis G., Uniunea Europeană- prezent şi perspective Ed. Didactică şi Pedagogică, Bucureşti, 2004.

6. Marchis G., Impactul extinderii Uniunii Europene asupra strategiilor şi politicilor regionale. Rolul Fondurilor Structurale, Teză de doctorat, A.S.E. Bucureşti, 2008.

7. Moussis N., Access to European Union, Rixensart, Belgium, 2009.

8. Schiavo-Campo Salvadore, Strenghtening Performance in Public Expenditure Management, 1995.

9. Zaccomer G.P., Shift-Share Analysis with Spatial Structure: an Application to Italian industrial Districts, Transition Studies Review, Springer Wien, Volume 12, no.1, 2006.

10. CIA World Factbook, 2006 Projections, IMF, 2005.

11. European Commission, Building our common future - Policy challenges and budgetary means of the enlarged Union 2007-2013, Brussels, $10^{\text {th }}$ of February 2004.

12. European Commission, Financial Perspectives 2007 - 2013, Brussels, $14^{\text {th }}$ of July 2004.

13. Guvernul României, Strategia pentru o reglementare mai bună la nivelul administrației publice centrale 2008 - 2013 - Document de politică publică -, Bucureşti, 2007.

14. *** Financial Perspective 2007-2013, CADREFIN 268, 15915/05, Council of the European Union, Brussels, 19 December 2005.

15. http://www.cnp.ro 